\title{
A NEW MICROMONOSPORA-PRODUCED MACROLIDE ANTIBIOTIC, ROSAMICIN*
}

\author{
G. H. Wagman, J. A. Waitz, J. Marquez, A. Murawski, \\ E. M. Oden, R. T. Testa and M. J. Weinstein \\ Microbiology Division, Schering Corporation, \\ Bloomfield, N. J., U.S.A.
}

(Received for publication August 21, 1972)

\begin{abstract}
A new antibiotic, rosamicin, classified as a macrolide, has been isolated from the fermentation broth of a new species of Micromonospora, $M$. rosaria. The antibiotic is separated from the broth by a solvent extraction procedure and purified by column chromatography. Chromatographic studies indicate that rosamicin is different from all related macrolides and is a novel antibiotic. It has broad-spectrum activity, although it is more potent against gram-positive organisms. Rosamicin is also active against Mycoplasma.
\end{abstract}

The first macrolide antibiotic to be isolated from a species of Micromonospora was megalomicin, produced by $M$. megalomicea. ${ }^{1)}$ A new macrolide antibiotic unrelated to megalomicin and named rosamicin has now been isolated from the fermentation broth of another new species of the genus Micromonospora. This paper presents initial data on the taxonomy of this new organism, and primary data concerning the chemical and biological properties of rosamicin.

\section{Materials and Methods}

The organism which produces rosamicin is a new species of Micromonospora, named $M$. rosaria and assigned NRRL No. 3718. This culture was isolated from a soil sample obtained from Little Thicket, San Jacinto County, Texas.

The colonial morphology of a 14-day old culture was determined after incubation at $24 \sim 26^{\circ} \mathrm{C}$ on an agar medium consisting of $\mathrm{N}-\mathrm{Z}$ amine type $\mathrm{A}, 3 \%$, dextrose, $1 \%$; and agar, $1.5 \%$. Macroscopically, no aerial mycelia are evident; colonies are slightly raised, granular to weakly folded. Growth is fair, glistening, and no diffusible pigment is produced. On an agar medium composed of yeast extract, $1 \%$ and glucose $1 \%$, a rosecolored diffusible pigment is produced.

The mycelia are regularly branched averaging $10 \sim 20 \mu$ in length and $0.6 \mu$ in diameter. Numerous chlamydospores are produced, up to $2 \mu$ in diameter. Conidia are not observed on the $\mathrm{N}-\mathrm{Z}$ amine medium.

The laboratory fermentation of $M$. rosaria is carried out in two stages, as follows:

a) Germination stage: A loopful of $M$. rosaria culture from an agar slant is used to inoculate a $300-\mathrm{ml}$ flask containing $100 \mathrm{ml}$ of the following sterile medium: beef extract, $3 \mathrm{~g}$; tryptose, $5 \mathrm{~g}$; yeast extract, $5 \mathrm{~g}$; dextrose, $1 \mathrm{~g}$; potato starch, $24 \mathrm{~g}$, calcium carbonate, $2 \mathrm{~g}$; tap water, $1,000 \mathrm{ml}$. The flask and its contents are incubated for 72 hours at $35^{\circ} \mathrm{C}$ on a rotary shaker with 2 -inch $(5.1 \mathrm{~cm})$ stroke at $280 \mathrm{rpm}$.

* Formerly named rosaramicin.

Presented in part at the Twelf th Interscience Conference on Antimicrobial Agents and Chemotherapy, Atlantic City, N. J. (USA), Sept. 27, 1972. 
b) Fermentation stage: Five $\mathrm{ml}$ of inoculum (from the germination stage) is transferred to a $500-\mathrm{ml}$ Erlenmeyer flask containing $100 \mathrm{ml}$ of the following sterile medium: Amber BYF No. 300, $7 \mathrm{~g}$; fish solubles, $1 \mathrm{~g}$; corn steep liquor solids, $1 \mathrm{~g}$; potato starch, $30 \mathrm{~g}$; calcium carbonate, $1 \mathrm{~g}$; tap water, $1,000 \mathrm{ml}$. The $\mathrm{pH}$ is adjusted to 7.2 before autoclaving. The flask and its contents are incubated for $72 \sim 96$ hours at $28^{\circ} \mathrm{C}$ on a rotary shaker as previously described.

The microbiological assay of rosamicin is a cylinder cup assay using Bacillus subtilis ATCC 6633 as the test organism.

The physical conditions of the assay consist of a base layer of $21 \mathrm{ml}$ and a seed layer of $4 \mathrm{ml}$ of Antibiotic Medium (Difco) No. 5. A commercial source of B. subtilis spores is used as the inoculum. The standard curve used in the assay has the following antibiotic concentrations: $0.64,0.8,1.0$ (reference point), 1.25 and $1.56 \mathrm{mcg}$ per $\mathrm{ml}$. The diluent used in the preparation of all dilutions is $0.1 \mathrm{M}$ phosphate buffer $(\mathrm{pH} 8.0)$.

The reference standard prepared as described has an assigned potency of $1,000 \mathrm{mcg} / \mathrm{mg}$. One mcg of this preparation in $1 \mathrm{ml}$ of $0.1 \mathrm{M}$ phosphate buffer analyzed under the conditions of this assay will elicit a zonal response of $17.8 \pm 1.0 \mathrm{~mm}$. The working standard is a preparation having a potency of $775 \mathrm{mcg} / \mathrm{mg}$ assayed against the reference standard.

The in vitro activity of rosamicin was studied by conventional tube dilution procedures using yeast beef broth at $\mathrm{pH} 7.4$.

The protective activity of rosamicin was tested in male CF-1 mice weighing approximately $20 \mathrm{~g}$ each. The antibiotic was given as a suspension or solution in an aqueous vehicle containing $0.5 \%$ carboxy methyl cellulose in two doses; shortly before, and 4 hours after intraperitoneal infection with bacteria. Infected, non-treated mice generally died 18 hours after infection while survivors in treated groups were determined 48 hours after infection.

\section{Results and Discussion}

\section{Isolation and Characterization}

Rosamicin is isolated from the fermented broth by a solvent extraction procedure. A 60 -liter fermentation is adjusted to a $\mathrm{pH}$ of 9.5 with sodium hydroxide and is extracted two times using 2 volumes of ethyl acetate, each time, for each volume of whole broth. After separation, the solvent phase is concentrated to a volume of 1.5 liters. The biological activity of a typical concentrate utilizing a disc $6.35 \mathrm{~mm}$ in diameter gives a zone diameter of $40 \mathrm{~mm}$ against Staphylococcus aureus and $22 \mathrm{~mm}$ against Pseudomonas aeruginosa. The active substance is separated from this concentrate with three $600 \mathrm{ml}$ extractions of $0.1 \mathrm{~N} \mathrm{H}_{2} \mathrm{SO}_{4}$. The aqueous phases are pooled and adjusted to a $\mathrm{pH}$ of 9.5 with sodium hydroxide and extracted two times in small segments with equal volumes of ethyl acetate. The solvent phase is separated and concentrated to a volume of about $70 \mathrm{ml}$. This concentrate is slowly added to a mixture of ether-hexane $(3: 2)$ with stirring. The resulting precipitate is filtered, discarded and the mother liquor evaporated to dryness. This residue is redissolved in $100 \mathrm{ml}$ of ethyl acetate and extracted three times with $25 \mathrm{ml}$ of water. The solvent phase is separated, dried over sodium sulfate, filtered and concentrated to dryness.

This material is now dissolved in $20 \mathrm{ml}$ of ethyl ether and insolubles if any, filtered and discarded. The ether solution is added to about $100 \mathrm{ml}$ of petroleum ether (b.p. $30 \sim 60^{\circ} \mathrm{C}$ ) and the resulting buff-colored precipitate filtered and dried under vacuum. The mother liquor is concentrated to a smaller volume affording additional precipitate which is also filtered, dried and combined with the initial 
precipitate. The weight of the combined precipitate is about $1.5 \mathrm{~g}$.

Material produced in this way has been assigned a working potency of about $700 \mathrm{mcg} / \mathrm{mg}$ of rosamicin complex according to the bioassay procedure previously described.

\section{Characterization and Properties of the Antibiotic}

Chromatography in a variety of systems differentiated rosamicin from all other groups of compounds except the macrolide group of antibiotics. Chromatography on thin-layer plates using a solvent mixture consisting of chloroform-methanol-17\% ammonia, 2:1:1 (lower phase), shows the similarity of rosamicin with other macrolide antibiotics (Table 1). Solvent mixtures consisting of butanol-water-acetic acid, $3: 1: 1$; and chloroform-methanol, $3: 2$ (Table 1) differentiated the antibiotic from a number of important macrolides except for cirramycin $A_{1}$. Cirramycin $A_{1}$ was differentiated from rosamicin chromatographically and by the comparison of several additional characteristics which are summarized in Table 2.

Bioautography following chromatography on thin-layer silica gel plates using a

Table 1. Comparative thin-layer chromatography of rosamicin with some macrolide antibiotics

\begin{tabular}{|c|c|c|c|c|}
\hline System & Antibiotic & Rf and color $b$ & $\mathrm{H}_{2} \mathrm{SO}_{4}$ spray* & $\begin{array}{c}\text { Rf of inhibition } \\
\text { zone** }\end{array}$ \\
\hline $\begin{array}{l}\text { Chloroform- } \\
\text { methanol-17 \% } \\
\text { ammonia, } 2: 1: 1\end{array}$ & $\begin{array}{l}\text { Rosamicin } \\
\text { Megalomicin } \\
\text { Oleandomycin } \\
\text { Erythromycin } \\
\text { Spiramycin } \\
\text { Carbomycin }\end{array}$ & $\begin{array}{ll}0.82 & 0.98 \\
0.97 & \\
0.78 & 0.95 \\
0.94 & \\
0.95 & \\
0.96 & \end{array}$ & $\begin{array}{l}\text { Tan } \\
\text { Black } \\
\text { Black } \\
\text { Brown } \\
\text { Red-brown } \\
\text { Purple }\end{array}$ & $\begin{array}{l}0.98 \\
0.97 \\
0.95 \\
0.94 \\
0.95 \\
0.96\end{array}$ \\
\hline $\begin{array}{l}\text { Butanol-acetic acid- } \\
\text { water, } 3: 1: 1\end{array}$ & $\begin{array}{l}\text { Rosamicin } \\
\text { Megalomicin } \\
\text { Erythromycin } \\
\text { Spiramycin } \\
\text { Oleandomycin } \\
\text { Carbomycin }\end{array}$ & $\begin{array}{ll}0.31, & 0.37 \\
0.44 & \\
0.21 & \\
0.38 \sim 0.45 \\
0.16, & 0.31 \\
0.35, & 0.45 \\
0.14, & 0.36 \\
0.58 & \end{array}$ & $\begin{array}{l}\text { Tan } \\
\text { Purple } \\
\text { Brown } \\
\text { Red-brown } \\
\text { Black } \\
\text { Purple }\end{array}$ & $\begin{array}{l}0.37 \\
0.21 \\
0.40 \\
0.16 \\
\\
0.36 \\
0.58\end{array}$ \\
\hline $\begin{array}{l}\text { Chloroform-methanol, } \\
\quad 3: 2\end{array}$ & $\begin{array}{l}\text { Rosamicin } \\
\text { Oleandomycin } \\
\text { Erythromycin }\end{array}$ & \multicolumn{2}{|c|}{-} & $\begin{array}{l}0.48 \\
0.28 \\
0.29\end{array}$ \\
\hline
\end{tabular}

* Plate heated at $100^{\circ} \mathrm{C}$ and sprayed with $\mathrm{H}_{2} \mathrm{SO}_{4}$ in methanol $(1: 1)$.

* Plated against Sarcina lutea.

Table 2. Comparative data; rosamicin and cirramycin $A_{1}$

\begin{tabular}{l|l|l}
\hline & Rosamicin & $\begin{array}{c}\text { Cirramycin } \\
A_{1}\end{array}$ \\
\hline $\begin{array}{l}\text { Chromatography } \\
\text { Silica gel G Plates, } \\
\text { chloroform-metha- } \\
\text { no1 (4 1), plated } \\
\text { against Sarcina lutea }\end{array}$ & Rf 0.51 & Rf 0.44 \\
Melting point & $119 \sim 122^{\circ} \mathrm{C} *$ & $124 \sim 128^{\circ} \mathrm{C}$ \\
pKa & 8.7 & 8.0 \\
Optical rotation & $-33.4^{\circ}$ & $-28.0^{\circ}$ \\
\hline
\end{tabular}

* From Reimann et al. ${ }^{3}$
Table 3. Chemical and physical properties of rosamicin

\begin{tabular}{l|l|l}
\hline $\begin{array}{c}\text { Elemental } \\
\text { analysis }\end{array}$ & Carbon & 63.18 \\
(average of & Hydrogen & 8.86 \\
2 determi- & Nitrogen & 2.29 \\
Oxygations) & (by difference) & 25.67 \\
\hline Optical rotation & {$[\alpha]_{\mathrm{D}}^{25}-33.4^{\circ}(c 0.3)$} \\
pKa & 8.7 \\
Neutralization equivalent & 599 \\
Ultra-violet spectrum & $\mathrm{E}_{1 \mathrm{~cm}}^{1 \%}=238(240 \mathrm{~nm})$ \\
\hline
\end{tabular}


Table 4. Solubility of rasamicin free base

\begin{tabular}{l|l}
\multicolumn{1}{c|}{ Solvent } & \multicolumn{1}{|c}{ Solubility* } \\
\hline Water & Slightly soluble \\
Methanol & Very soluble \\
Acetone & Very soluble \\
Chloroform & Very soluble \\
Benzene & Very soluble \\
Ether & Sparingly soluble \\
\hline
\end{tabular}

* According to U.S. Pharmacopeia, 17 th revision (1965) p. 8

solvent system consisting of chloroform-methanol (4:1) indicates that rosamicin consists of one major antibiotic component ( $\mathrm{Rf}$ 0.51 ) and at least two minor active components ( $\mathrm{Rf}$ 's 0.16, 0.31).

Rosamicin complex gives a
Table 5. Comparative stability study; rosamicin and erythromycin

\begin{tabular}{c|c|c|c}
\hline \multirow{2}{*}{$\mathrm{pH}^{*}$} & \multirow{2}{*}{ Minutes at $100^{\circ} \mathrm{C}$} & \multicolumn{2}{|c}{ Potency $(\mathrm{mcg} / \mathrm{ml})$} \\
\cline { 3 - 4 } & & Rosamicin & Erythromycin \\
\hline 2.2 & 0 & 242 & $<10$ \\
& 30 & 121 & $<10$ \\
4.0 & 0 & 218 & 249 \\
& 30 & 240 & $<10$ \\
6.0 & 0 & 210 & 257 \\
7.0 & 30 & 180 & 207 \\
& 0 & 224 & 254 \\
8.0 & 30 & 234 & 242 \\
& 0 & 250 & 259 \\
9.0 & 30 & 206 & 250 \\
& 0 & 228 & 257 \\
10.0 & 30 & 146 & 164 \\
& 0 & 236 & 246 \\
\hline
\end{tabular}

* McIlvaine's buffers from pH $2.2 \sim 8.0$; borate buffer at $\mathrm{pH}$ $9.0 \sim 10.0$.

positive color reaction in the Molisch, Starch-KI and Elson-Morga. tests and a negative color reaction in the biuret, ninhydrin and SAKAGUCHI tests. The ultraviolet absorption spectrum in $95 \%$ methanol displays a peak $\left(\mathrm{E}_{1 \mathrm{~cm}}^{1 \%} 238\right)$ at $240 \mathrm{~nm}$.

Separation of the major component is achieved by dissolving rosamicin complex in a mixture of chloroform-methanol $(9: 1)$ and adsorbing this solution at the top of a silicic acid column. The column is eluted with chloroform-methanol $(4: 1)$ and fractions are collected. The column is monitored by disc testing each fraction against $S$. aureus. The fractions are chromatographed on silica gel thin-layer plates, developed for 1 hour in a chloroform-methanol (4:1) solvent system. The patterns of the antibiotic fractions are determined by chromatography and detected by bioautography and sulfuric acid treatment of the plates. Also, by viewing the sulfuric acid sprayed plates under a U.V. source after heating some biologically inactive materials fluorescence under U. V. light and therefore become apparent. Fractions are combined according to their chromatographic patterns and are concentrated.

By this method, rosamicin was separated and isolated after pooling similar active fractions, drying, dissolving in acetone and precipitating with ethyl ether. The mother liquor is now evaporated to dryness yielding the antibiotic as a white powder. Rosamicin at this stage exhibits a defined potency of $1,000 \mathrm{mcg} / \mathrm{mg}$.

The chemical and physical properties of rosamicin are summarized in Table 3 and solubility characteristics are shown in Table 4. Desosamine was found to be present (procedure of FLYNN et al. ${ }^{2)}$ ) and identical to an authentic sample by paper chromatographic comparison using a solvent mixture of butanol-pyridine-acetic acid - water $(6: 4: 1: 3)$. Additional chemical studies and elucidation of the structure of rosamicin are given in REIMANN et al. ${ }^{3}$

A stability study comparing rosamicin base with erythromycin base is shown in Table 5. Buffered solutions containing approximately $250 \mathrm{mcg} / \mathrm{ml}$ of each antibiotic were made up in a range of $\mathrm{pH} 2.2 \sim 10$. Samples were taken at 0 and 30 minutes 
after heating in closed tubes at $100^{\circ} \mathrm{C}$ in a boiling water bath, cooled rapidly and submitted for microbiological assay. As is illustrated in Table 5 , rosamicin is much more stable than erythromycin under acid conditions, has a similar pattern at midrange through $\mathrm{pH} 9$ and is somewhat less stable at $\mathrm{pH} 10$.

The antibiotic has been tested for stability against trypsin, chymotrypsin, pepsin, and $\alpha-$ amylase at the optimal condition for activity of each enzyme. The antibiotic was stable to all of the enzymes tested for up to 24 hours at $37^{\circ} \mathrm{C}$.

In Vitro Antimicrobial Activity of Rosamicin

The results of in vitro tests in which rosamicin was compared with erythromycin and megalomicin A are shown in Table 6 and demonstrate
Table 6. In vitro activity of rosamicin

\begin{tabular}{l|l|l|l|l}
\hline \multirow{2}{*}{ Organism } & No. & \multicolumn{3}{|c}{ MIC (mcg/ml) } \\
\cline { 4 - 5 } & Strains & Rosamicin & $\begin{array}{c}\text { Megalo- } \\
\text { micin } \\
\text { A base* }\end{array}$ & $\begin{array}{c}\text { Erythro- } \\
\text { mycin } \\
\text { base* }\end{array}$ \\
\hline Staphylococcus aureus & 6 & $0.03 \sim 3.0$ & 0.3 & $0.01 \sim 0.75$ \\
Streptococcus pyogenes & 7 & $0.75 \sim 3.0$ & $0.3 \sim 7.5$ & $0.3 \sim 0.75$ \\
Enterococcus sp. & 2 & $0.03 \sim 0.08$ & $0.75 \sim 3.0$ & 0.3 \\
Diplococcus pneumoniae & 3 & $0.03 \sim 0.08$ & 3.0 & 3.0 \\
Escherichia coli & 3 & 3.0 & $0.3 \sim 7.5$ & 7.5 \\
Klebsiella pneumoniae & 4 & $0.3 \sim 3.0$ & $0.75 \sim>25$ & 7.5 \\
Aerobacter aerogenes & 3 & $0.75 \sim 7.5$ & $7.5 \sim>25$ & - \\
Proteus sp. & 3 & 0.3 & $0.3 \sim 0.757 .5$ \\
Pseudomonas aeruginosa & 4 & $0.75 \sim 3.0$ & $0.75 \sim 7.5$ & 12.5 \\
Salmonella schottmuelleri & 3 & $0.3 \sim 3.0$ & $0.3 \sim>257.5$ \\
Mycoplasma gallisepticum & $1 * *$ & 0.05 & 0.05 & - \\
\hline
\end{tabular}

Medium: Yeast beef broth $\mathrm{pH} 7.4$. Incubated 18 hours at $37^{\circ} \mathrm{C}$

* Not performed at the same time with same strains.

** PPLO broth and agar.

Table 7 . Effect of $\mathrm{pH}$ on in vitro activity of rosamicin

\begin{tabular}{|c|c|c|c|c|c|c|}
\hline \multirow{2}{*}{ Organism } & & \multicolumn{5}{|c|}{ MIC $\quad(\mathrm{mcg} / \mathrm{ml})$} \\
\hline & & $\mathrm{pH} 6.6$ & $\mathrm{pH} 7.0$ & pH 7.4 & $\mathrm{pH} 7.7$ & $\mathrm{pH} 8.0$ \\
\hline Staphylococcus aureus & 2933 & 0.6 & 0.3 & 0.3 & 0.15 & 0.15 \\
\hline " 11 & $209 \mathrm{P}$ & 0.6 & 0.3 & 0.15 & 0.075 & $<0.05$ \\
\hline$\|$ & Gray & 1.2 & 0.6 & 0.6 & 0.3 & 0.3 \\
\hline Streptococcus pyogenes & $\mathrm{C}$ & 1.2 & 0.6 & 0.3 & 0.3 & 0.3 \\
\hline Escherichia coli & 10536 & $>6.4$ & $>6.4$ & $>6.4$ & 6.4 & 4.8 \\
\hline
\end{tabular}

Medium: Yest beef broth

Table 8. Effect of rosamicin against erythromycinresistant strains

\begin{tabular}{|c|c|c|c|c|c|c|}
\hline \multirow{3}{*}{\multicolumn{2}{|c|}{ Organism }} & & \multicolumn{4}{|c|}{$\mathrm{MIC} \quad(\mathrm{mcg} / \mathrm{ml})$} \\
\hline & & & \multicolumn{2}{|c|}{ Rosamicin } & \multicolumn{2}{|c|}{ Erythromycin } \\
\hline & & & $\mathrm{pH} 7$ & $\mathrm{pH} 8$ & $\mathrm{pH} 7$ & $\mathrm{pH} 8$ \\
\hline Staphylococcus & aureus & 2033 & 1.2 & 0.4 & 25 & 18 \\
\hline$u$ & 11 & 303 & $>50$ & 4.9 & 62 & 18 \\
\hline$\prime \prime$ & $\| \prime$ & 388 & $>50$ & 4.9 & 62 & 18 \\
\hline Streptococcus & pyogenes & 33 & $>50$ & 50 & 62 & 62 \\
\hline
\end{tabular}

Medium: Yest beef broth

that it has a broad antibacterial spectrum in vitro with greatest activity against gram-positive bacteria. Its activity against gram-negative bacteria appears to be considerably greater than that evidenced by erythromycin.

The effect of $\mathrm{pH}$ on the in vitro activity of rosamicin was tested against a select group of organisms (Table 7). As with other macrolides, rosamicin has greater activity at higher $\mathrm{pH}$ levels. Of interest is the fact that the greatest shift in activity for the antibiotic occurs around $\mathrm{pH} 7.5$, while the shift for erythromycin occurs at $\mathrm{pH} 7.7$ and for megalomicin $\mathrm{A}$ it occurs at $\mathrm{pH} 7.8 \sim 8.0$. Rosamicin thus has less diminution of activity in the physiological $\mathrm{pH}$ range.

The antibiotic was studied in vitro against a limited number of erythromycinresistant $S$. aureus and $S$. pyogenes strains (Table 8 ). It was effective against one, and moderately active against 2 of the 3 resistant Staphylococcus strains studied. 
It is also effective against Mycoplasma species, which are detailed by WAITz et al. ${ }^{4}$

In Vivo Activity of

\section{Rosamicin}

The results of limited protection tests with rosamicin in comparison with erythromycin and megalomicin $\mathrm{A}$ are shown in Table 9. This preparation was active when given parenterally and orally against lethal infections of Staphylococcus aureus and Streptococcus pyogenes. Further tests, particularly with gram-negative infections, are described by WAITz et al. . $^{4}$

The intraperitoneal acute toxicity of the antibiotic $\left(\mathrm{LD}_{50}\right)$ was $350 \mathrm{mg} / \mathrm{kg}$ (Table 5), $625 \mathrm{mg} / \mathrm{kg}$ when given subcutaneously, and $155 \mathrm{mg} / \mathrm{kg}$ intravenously.

The intraperitoneal $\mathrm{LD}_{\tilde{a} 0}$ for rosamicin is similar to erythromycin and megalomicin $A$, but it is more toxic than these two antibiotics when given subcutaneously. This may be due to the aqueous solubility and improved absorption of rosamicin compared to the low solubility of the base forms of megalomicin $A$ and erythromycin.

Based on the biological data available, rosamicin appears to have in vitro and in vivo properties typical of other macrolides with better gram-negative activity and activity against some erythromycin-resistant strains. These data, along with its apparent stability, suggest that further investigation of rosamicin is warranted.

\section{Acknowledgements}

We wish to acknowledge the technical assistance of JANET V. BATLEY who carried out many of the chromatographic studies.

\section{References}

1) Weinstein, M. J.; G. H. Wagman, J. A. Marquez, R. T. Testa, E. M. Oden \& J. A. Wattz: Megalomicin, a new macrolide antibiotic complex produced by Micromonospora. J. Antibiotics $22: 253 \sim 258,1969$

2) Flynn, E. H.; M. V. Segel, P. F. Wiley \& K. Gerzan : Erythromycin. I. Properties and degradation studies. J. Am. Chem. Soc. $76: 3121 \sim 3131,1954$

3) ReImanN, H. \& R.S. JARET : The structure of rosamicin. Chem. Comm. In press

4) Waitz, J. A.; C. G. Drube, E. L. Moss, Jr. \& M. J. Weinstein : Biological studies with rosamicin, a new Micromonospora-produced macrolide antibiotic. J. Antibiotics $25: 647 \sim 652,1972$ 